\title{
Impact of Job Insecurity and Work Overload on Employee Performance With the Mediating Role of Employee Stress: A Case of Pakistan's Fast-food Industry
}

\author{
Arslan Shoaib Naru \\ Assistant Professor, National University of Computer and Emerging Sciences, Lahore, \\ Pakistan \\ E-mail: arslanshoaib@gmail.com
}

\begin{abstract}
Anam Rehman
Lecturer, National College of Business Administration, Lahore, Pakistan

E-mail: anam_rehman16@hotmail.com
\end{abstract}

Received: Oct. 30, 2019 Accepted: Feb. 14, 2020 Online published: Feb. 24, 2020

doi:10.5296/ijhrs.v10i1.15741 URL: https://doi.org/10.5296/ijhrs.v10i1.15741

\begin{abstract}
The fast-food industry is one of the booming industries in Pakistan with rapidly developing human resources. However, quick growth has become impeded by numerous human resource management challenges. The purpose of this study is to investigate factors/variables that cause stress among employees in the workplace which consequently affect their performance. Pakistan's fast-food sector has been taken into account and a comprehensive study has been carried out to find out which variables result in employee stress and affect their overall job performance. Primary data was collected through three hundred and fifty questionnaires disseminated throughout various areas of Lahore, Karachi and Islamabad including Emporium Mall, Packages Mall and Dolmen Mall, Lucky One Mall, Centaurus, and key areas popular for fast-food in those cities. Several statistical tools including; Reliability and Validity Analysis, Factor Analysis, Regression analysis, KMO, Cronbach Alpha and the Bartlett Test, are used for data analysis on SPSS and Smart PLS. Results of the analysis show that Work Overload, Job Insecurity (independent variable) and Employee Stress (mediating variable) have a significant impact on Employee Performance (dependent variable). The
\end{abstract}


relationship of Job Security and Work Overload with Employee Stress is positive. Similarly, the relationship between Employee Stress and Employee Performance is also positive and significant. The study described in this paper thoroughly focuses on all the major causes of employee's stress and its impact on employee performance, it also suggests how Fast-food sector of Pakistan should consider these factors in order to address these issues and provide favorable workplace environment.

Keywords: work overload, job insecurity, employee stress, employee performance, fast-food industry

\section{Introduction}

\subsection{Background of the Study}

In the past, employees were taken as an expense by the organizations. However, with the passage of time, that changed and employers began seeing them as a valuable resource. Presently, employers recognize that talented and motivated employees are crucial for organizational productivity and profitability. Thus employers are finding ways to motivate employees to improve their performance (Lee, 2011).

Job insecurity can be expressed as "the powerlessness to maintain desired continuity in a threatened job situation" (Greenhalgh, 1984). Recently, job insecurity has been a growing concern for employees. Uncertain economic times and increasing competitive standards have contributed to higher levels of job insecurity. This may have a detrimental effect on employee performance (Sverke, 2002).

Moreover, given the globalization, intense competition and economic changes organizations are pursuing acquisitions, mergers and structural changes which create a feeling of job insecurity among employees (Sverke, 2002). Job insecurity results in negative job outcomes, as employees work in uncertain environment, they become distracted by fear of losing their role and they lose confidence to perform optimally. As these fears loom, they may become prone to consistent low productivity and poor performance. Despite pervasive dilemma of job insecurity in contemporary organizational context, ample research remains yet to be conducted to identify repercussions of job insecurity and as a result only limited literature is available on it by scholars and organizational researchers (Ashford, 1989).

Another factor that negatively affects employee performance is work overload (Brown \& Benson, 2005). Work overload has been defined as the extent to which the "job performance required in a job is excessive or overload due to performance required on a job" (Iverson \& Maguire, 2000). When a person is overly occupied with work, it is common for him to spend most of his personal time at the workplace, which affects his work-life balance (Duxbury \& Higgins, 2001). This not only causes mental and physical health issues, but it also leads to lack of enthusiasm, absenteeism, and poor performance (Ivancevich, 1985).

Apart from job insecurity and work overload, employee stress is another major factor that is negatively correlated to employee performance. Employee stress can be expressed as "a situation, where the demands of the external situation are beyond a person's perceived ability 
to deal with them" (Lazarus, 1966). Conventionally, it was believed that stress is good for employees as it motivates them to do work. But further studies have pointed out that stress is related to negative job outcomes.

Studies suggest that employee stress leads to increased organizational health-care costs, that workplace stress is one of the major reasons of deaths among employees in the United States, and health-care expenditure is approximately 50 percent more for those employees who report having stress than others (Colligan \& Higgins, 2005). According to an analysis, about 20 percent of a company's payroll goes towards coping with stress related problems (Riga, 2006).

Although, various factors may lead to employee stress but two major factors are 'work overload' and 'job insecurity'.

Work overload is one of the most pervasive factors in the study of employee stress. The accelerated pace of modern lifestyles have subjected us to frequent stress. Businesses need to adapt to rapid changes and employees must deal with work overload such as information surplus or tough competition (DeFrank \& Ivancevich, 1998). Work pressures also impact ill health. It is said that employees who feel that they have a lot of tasks to do and must work for long hours often report to have stress and other health issues. Men reporting high job pressure or demands increasingly sought more medical attention and showed more documented signs of pathology. Moreover, research demonstrates a stronger relationship between reported work overload and physical health complaints than between number of hours worked and poor health (Taylor, Repetti, \& Seeman, 1997). In fact, it is said that one of the main causes of psychological illness is work overload. It affects their personal lives, leads to lack of control over work; lack of participation in decision making, poor social support and unclear management and work role (Michie \& Williams, 2003). Research shows that work overload negatively affects job commitment. While Organizational commitment may become affected by organizational adaptability or turnover but employees facing work overload may have lesser job commitment(Stevens, Beyer, \& Trice, 1978). Similarly, employees under high workload would have lower job satisfaction. High workload with little or no breaks would leave employee over worked and impact the quality of outcome hence lowering employee's work satisfaction (Iverson \& Maguire, 2000) Therefore, given these aspects work overload presents array of factors that lead to employee stress eventually lowering employee performance.

On the other hand Job insecurity is a subjective perception. It is related to insecurity about the future. Insecure employees are unclear about whether they will retain or lose their present job. It is a that leads to employee stress. Given the globalization, intense competition and economic changes organizations pursue acquisitions, mergers and structural changes which generate feelings of job insecurity among employees (Sverke, 2002). Thus, job insecurity results in negative job outcomes and it serves as the second major factor in this research.

\subsection{A Glimpse of the Fast-food Industry of Pakistan}

Fast-food is the 2nd largest industry in Pakistan and 8th largest in the world, with more than 
180 million consumers.

Despite Pakistan being an under-developed country, its fast-food industry is growing vigorously and the main reasons of this growth are the changing life styles, changes in traditional eating practices and the induction of women in the workforce. According to a survey of the fast-food industry performance in Pakistan, approximately 40 to 42 percent of a person's income is consumed over food. The industry is growing at a pace of 20 percent annually (Azam, 2017).

Since, rapid growth, intense competition, and increased consumer demands are compelling managers to ensure that their employees provide quality products and services to their customers. This study is conducted to find the factors that affect employee performance in the fast-food industry of Pakistan.

\subsection{Fast-Food Chains in Pakistan}

Following are some of the most prominent names in Pakistan's Fast-food Industry:

- Johnny Rockets

- $\quad$ Fat Burger

- $\quad$ Burger King

- Hardees.

- Domino’s Pizza

- Subway

- Pizza Hut

- McDonald's

- $\mathrm{KFC}$

\subsection{Management Dilemma}

Today, in the era of globalization and intense competition, managers need to identify and resolve various stress related factors that impede employee performance. In Pakistan, managers are presented with dire circumstances; lack of resources in faces of high consumer demands, tough competition and unpredictable economic and political landscape keeps them scrambling for productivity. It is not easy for them in Pakistan since fast-food industry has mushroomed and expanded at an unprecedented pace. It is one of the fastest-growing markets in the world which makes their job even more difficult.

\subsection{Problem Definition}

Work overload and job insecurity are two major factors that cause employee stress and decline in employee performance.

Hence, the problem statement of the current study is: 


\section{Macrothink

"How can management address the Performance Challenges in the Fast-food industry?"

\subsection{Purpose of the Study}

The purpose of this study is to examine the impact of job insecurity and work overload on employee stress and resultant decline in employee performance in the fast-food sector of Pakistan. This will help the management of fast-food restaurants to address employee stress at workplace enable them to improve their performance.

\subsection{Significance of the Study}

This study is aims to examine the impact of job insecurity and work overload on employee performance with the mediating role of employee stress. This study is unique because it intends to add value to the fast-food industry of Pakistan.

Employee stress has become one of the mainstream issues at workplace. Employees working in various types of food related organizations are suffering from stress caused by high workload and job insecurity because of market demands and cost cutting approach widely taken by many organizations. These factors directly affect employee performance. Pakistan is the sixth most populated country in this world. The fast-food sector in Pakistan is expansive and complex. Many studies have been made worldwide about fast-food sector of different countries but few have illustrated the intricacies of fast-food sector of Pakistan.

This study aims to apprise managers of how work overload and job insecurity proliferate within organizations that lead to workplace stress and affect the performance of their employees. Moreover, it will help managers in understanding that how stress affects a person's performance and what are some ways in which stress and performance can be managed.

\subsection{Research Questions}

The following three research questions were developed for this study:

1. Is there any impact of job insecurity on employee stress?

2. Is there any impact of work overload on employee stress?

3. Is there any impact of employee stress on employee performance?

\section{Literature Review}

The following chapter shows how employee stress affects employee performance which is a significant variable for the nature of today's situation and its determinants in the fast-food industry of Pakistan.

\subsection{Description of Variables}

This research is conducted to highlight some of the major problematic factors which increase or decrease employee performance. 
- To help employers, to measure the key problems inside their organization and to compare their performance with national standards, a self-report survey instrument has been developed by incorporating relevant components from Health and Safety Executive (HSE) indicator tool. Thirty five items are included in HSE Indicator Tool within the seven hazard categories (Marcatto, Colautti, Larese, Luis, \& Ferrante, 2014).

- Pace of work, working hours and workload are included in demands.

- Level of autonomy is measured through control measures over working methods, pacing, and timing degree of respect and help received from colleagues encompassed through peer support.

- Supportive behaviour of managerial support reflects through line managers and the organization, such as encouragement and feedback.

- Level of conflicts within the workplace assessed through relationships, which includes harassment and bullying behaviour.

- The level of role clarity has been examined by the role, and the maximum limit to which employees think that the contribution of their work is put into the overall goals of the organization.

- Either organizational changes are managed and communicated properly or not, are reflected through then change management approaches used.

Occupational groups, individual organizations and sectors normally use the HSE risk assessment approach to diagnose the stressful aspects of work. Different hazard categories within the workforce of employers has been assessed through that process, and precisely targeted interventions had been developed by them to increase the work-related conditions of their staff.

\section{Job Insecurity}

Job insecurity is known as "the perceived powerlessness to maintain the desired continuity in a threatened job situation" (Greenhalgh, 1984). The inability to consistently work can be attributed to unsuitable job environment. The perception of a potential threat to the continuity of the current job may be due to perceived apprehension of ones losing their organizational role and thus an employee could subjectively experience anticipation of a fundamental and involuntary event related to job loss (Sverke, 2002).

Job insecurity is a subjective perception. A given situation (e.g. a decline in company orders) may be understood in various ways by different employees. It may incite feelings of job insecurity for some. Moreover, what characterizes this subjective conceptualization of job insecurity is that it is related to insecurity about the future: Insecure employees are unclear about whether they will retain or lose their present job.

Research on job insecurity does not emphasize on employees who are compelled to choose an unsure job status (e.g. prefer to work with a temporary contract, because it is their best option in their present situation). Insecure employees rather experience an inconsistency between the 
preferred and the perceived level of security presented by their employer. A feeling of powerlessness is also emphasized in many definitions (Greenhalgh, 1984). Job insecurity mostly suggests feelings of helplessness to maintain the desired job continuity.

Job insecurity has been considered from two points of view as a multi-dimensional concept or as a global concept. Primarily, it is defined as "sense of powerlessness to maintain desired continuity in a threatened job situation" (Greenhalgh, 1984). In terms of the latter viewpoint, job insecurity indicates the threat of job loss and job discontinuity (Witte, 1999). Hence, job insecurity is an individual's expectations about continuity in a job situation (Davy, Kinicki, \& Scheck, 1997); i.e. the perception of a potential threat to continuity in his or her current job (Heaney, Israel, \& House, 1994).

\section{H1: Job insecurity has an impact on employee stress}

\section{Work Overload}

Workload is defined as the theoretical relationship between a group and individual human and job demands. Work overload is known as employees' perceptions that they are burdened with more work than they can finish within the allotted time (Spector \& Jex, 1998). Overworked people usually have irrational workloads; long work hours; go through tough routines; feel pressurized to work overtime; get no or little breaks and few days off. A different perspective on job overload terms it as an incompatibility among the necessities, time constraints and resources linked with work offered to fulfill these needs (Rizzo, House, \& Lirtzman, 1970).

Previous studies emphasized time dimension as an important base for work overload. Work overload was seen as a portion of role conflict (Newton \& Keenan, 1987). These days work overload is an isolated variable from role conflict. It was observed that work overload is related to the sentiments of tension, obstruction, range of sick days, trouble, depression, consideration to job burnout, losing elf-esteem, concentration issues and workplace accidents (Kahn \& Byosiere, 1992).

Work overload generates a hazard to the worker in performing his work efficiently, will increase withdrawal behavior patterns i.e. increase in number of sick days, anxiety, depression, loosing self-confidence, concentration problems (Pelletier, 1992).

\section{H2: Work overload has an impact on employee stress}

\section{Employee Stress}

"Stress is a multivariate process involving inputs, outputs and the mediating activities of appraisal and coping" (Lazarus, 1966). Occupational stress is known as the insight of an inconsistency between stressors and individual capabilities to fulfil these demands in the job environment (Vermunt, 2005). Stressors are known to cause stress. Stress can be positive when it inspires and encourages (Selye, 1956). On the other hand, distress is the bad stress, the one that gets the individual irritated and eventually leads to adverse consequences (Rees \& Redfern, 2000).

According to the Person-Environment Fit (PE-Fit) theory, stress at work comes into action 
when a person performs his job, particularly when the perplexing environment at job creates a hazard for the person, which ends up in an incompatible PE-Fit and ultimately leads to physical and psychological strain (Edwards, Caplan, \& Van Harrison, 1998). Further studies using Demand-Control model of job strain mention that workers experiencing high psychological demands (e.g. high workload and conflicting roles) and low decision latitude (e.g. having no freedom in one's job) are more likely to face distress. The Demand-Control model also highlighted the positive effects of social support from supervisors and colleagues (Karasek Jr, 1979)

The PE-Fit theory and the Demand-Control model are viewed as two of the most significant contributions to explain and describe employee stress, and they have guided the construction of many determinants of job stress (Vagg \& Spielberger, 1998).

Job stress occurs when there is an imbalance between the job demands, capabilities and skills of a worker to handle these job demands (Blaug, Kenyon, \& Lekhi, 2007). "Stress is a combination of physical and psychological reactions to events that challenge or threaten us. In normal circumstances, the stress response is a powerful protective mechanism that allows us to deal with sudden changes, dangers or immediate demands. In abnormal circumstances, stress overwhelms our protective mechanisms, leading to serious negative health outcomes" (CUPE, 2003).

\section{Employee Performance}

In the organizational context, performance is known as the extent to which an organizational member participates in fulfilling the goals of the firm. Employees are the main foundation of competitive advantage in service-oriented organizations (Pfeffer, 1994). Furthermore, a commitment to performance approach views workers as resources or assets, and values their voice and opinions.

Employee performance plays a vital role in organizational performance. Employee performance is formerly what an employee does or does not do. The Performance of employees includes the following: quantity of output, quality of output, timeliness of output, presence at work, cooperativeness (Güngör, 2011).

Enhanced individual employee performance could increase organizational performance (Macky \& Boxall, 2007). From outcome oriented approach, the record of outcomes obtained, for each job function, during a certain point of time. In this way, performance is viewed as a distribution of outcomes attained, and performance can be measured by using a number of factors that describe and explain an employee's patent of performance over time (Deadrick \& Gardner, 1997).

On the contrary, employee's performance is seen as a rating system used in many organizations to decide the competencies and productivity of an employee. Good employee performance is known to be associated with increased consumer perception of service quality, whereas poor employee performance has been related to increased customer complaints and brand switching (Darden \& Babin, 1994). 


\section{Mnacrothink \\ International Journal of Human Resource Studies

\section{H3: Employee stress has an impact on employee performance}

\subsection{Research Model and Hypothesis}

On the basis of the above literature, our research tests the following hypotheses:

H1: Job Insecurity has an impact on Employee Stress.

H2: Work overload has an impact on Employee Stress.

H3: Employee Stress has an impact on Employee Performance.

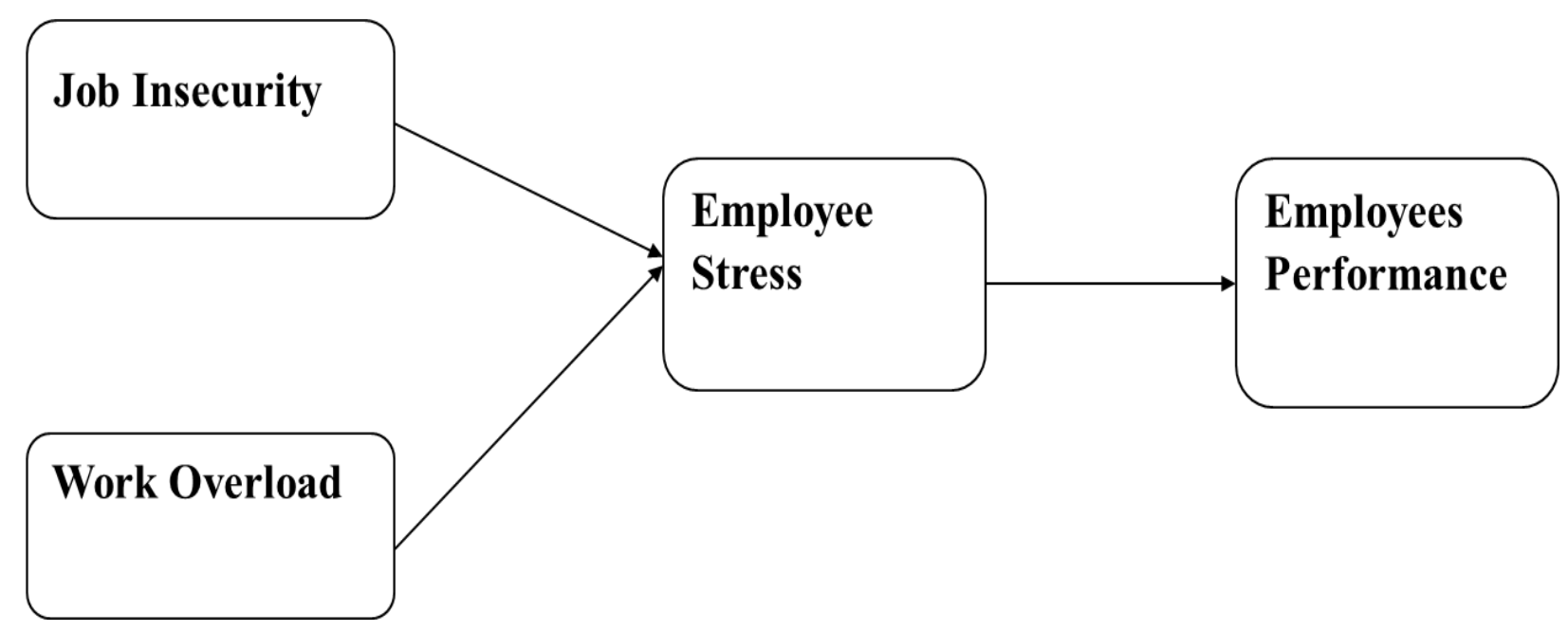

Figure 1. Research Model

\section{Research Methodology}

\subsection{Research Design}

The nature of research conducted by us is 'causal'. This type of research attempts to reveal a cause and effect relationship between two variables. This type of research is undertaken to show the effect of independent variable on dependent variables.

Causal research can be defined as research that includes exploring the effect of one thing on another thing and more specifically the effect of one variable on another. In order to conduct causal research, one must hold one variable (the one that is suspected to cause the change in the other variables) constant to measure other variables.

Moreover, this research was descriptive and cross-sectional in nature. Descriptive research describes a phenomenon or any situation. Descriptive research describes the existing situation instead of interpreting and then making judgments. The research was descriptive as it comprised of a survey and facts were found to meet objective requirements of the research. Furthermore, the research collected quantitative data which was gathered once at a point (cross-sectional) and was statistically tested (Williams, 2007). It shall facilitate in determining relationships between variables. 


\subsection{Population and Sample Data}

The population consists of the set of all measurements in which the investigator is interested (Aczel \& Sounderpandian, 1999). This research is conducted on the population of employees of the fast-food sector in the urban cities of Lahore, Karachi and Islamabad. The main areas from which data were collected are Emporium Mall, Packages Mall and M.M Alam. The Sample size is the number of completed responses that the survey receives. The data was gathered from a total of Three hundred and fifty respondents. For this study, the convenience sampling technique was used to collect data from respondents.

\subsection{Instruments and Measures}

For our study, the reliance is largely on the information that is collected by a questionnaire. A questionnaire is an instrument of research which consists of a series of questions for the purpose of gathering information from respondents to help in the research process. The main objective of a questionnaire is to obtain reliable and accurate responses from a chosen sample, with the aim of finding out what a chosen group of members do, think or feel (Collis \& Hussey, 2003). Thus, we feel that the questionnaire approach is essential for collecting data for our project. Questionnaires have advantages over some other type of surveys as they are quick and easy to use, require less effort as compared to verbal or telephone surveys. It has standardized answers that make it easy to compile data.

The questionnaire is scaled on the Likert Scale of 5 classes that range from " $1=$ Strongly Disagree" to " $5=$ Strongly Agree. All the instruments were designed carefully according to the context and scope of our study. Pilot testing was required as some of the items were redesigned to fit the scope. In pilot testing, validity and reliability of the questionnaire were ensured. Reliability was tested in both SPSS and Smart PLS, and shows satisfactory results using different tests. Convergent and discriminant validity tests were also applied to check the validity of all the variables as their items and measures were new or redesigned.

\subsection{Data Analysis Tools}

For data analysis, two main software were used i.e. IBM SPSS 21 and PLS 3.0. The methods employed in this software were pilot testing of variables, factor analysis, path analysis, reliability and validity tests and bootstrapping. These methods were used since they depicted lucid data analysis results.

In SPSS, Factor Analysis groups similar variables into the dimension. Factor analysis helps summarize our data. This helps attain information that which is relevant. Thus, rather than representing the same information again, we use a single factor. The factors if once identified then the extent to which each question belongs to that factor is then determined. This is the factor loading and is the correlation coefficient of the extent to which each question measures that factor. The greater the loading the more that item represents the factor. Hence the basic purpose of factor analysis is data reduction. Factor analysis is a technique used for considering the relationship between variables of different concepts. The purpose of this analysis is to see which data is meaningful, if not, then it is excluded. Certain criteria were used to see which variable should be included. It also allows us to give construct validity's 
evidence. KMO and Bartlett's test being the first and Principle Component Analysis being the second.

\section{Data Analysis Techniques and Findings}

Factor analysis is used to identify and analyze the underlying pattern in the data set. We conducted factor analysis for all the variables and its results are as follows. For our research study, we conducted the Factor Analysis with the help of SPSS software. Factor analysis is a method of data reduction. It is used to reduce the number of the item and to disclose the underlying dimensions on the tested scale.

After running this test there are certain values which need to be interpreted which are as follows:

\subsection{KMO and Bartlett Test}

Table 1. KMO and Bartlett Test

\begin{tabular}{|l|l|l|}
\hline Variable & KMO Test & $\begin{array}{l}\text { Significance Value of Bartlett } \\
\text { Test }\end{array}$ \\
\hline Work Overload & .672 & .000 \\
\hline Job Insecurity & .808 & .000 \\
\hline Employee Stress & .876 & .000 \\
\hline Employee Performance & .882 & .000 \\
\hline
\end{tabular}

KMO test is named after three scientists, Kaiser, Meyer, and Olkin and tells whether the sample size used for the study is adequate or not to perform the factor analysis. Its value should be greater than 0.60 (60 percent), in order to be acceptable. The higher the sample size, the higher the value of KMO tests. In the above table, the values of the KMO test are greater than 0.60 for all the variables and this means that the sample size used for this study is adequate to perform factor analysis.

On the other hand, the Bartlett test explains that whether the data can be rotated within the sphere to perform factor analysis or not. Its significance value should be less than 0.05 (5 percent), otherwise, factor analysis cannot be performed. For this study, the significance value of the Bartlett test for all the variable is less than 5 percent, which means that all the values are acceptable.

During the first stage, we firstly conducted KMO and Bartlett's test. KMO helps us with knowing whether the sample is adequate or not. The range is from 0 to 1 and the minimum being 0.5 and values closer to 1 are better. It is important as it tells the adequacy of the sample. The KMO was calculated for all the constructs as the results of the analysis are 


\section{Macrothink}

International Journal of Human Resource Studies

ISSN 2162-3058 2020, Vol. 10, No. 1

shown above. The KMO value for all the constructs is greater than 0.6 which is a better and reliable measure and approves the adequacy of the data collected. Bartlett's Test should be significant (e.g. $p<.05)$. This then tells us that whether our study is significant or not.

\subsection{Factor Loadings and Variance Explained}

The total amount of variance in the original variables that was accounted for each component is known as total variance explained. Its variance explains by any construct should be greater than 0.50 . For that matter, it would be better to collect some more data for better cumulative variance.

The table below explains factor loadings \& variance explained (SPSS):

Table 2. Factor Analysis

\begin{tabular}{|c|c|c|c|}
\hline Variables & Construct & Factor Loadings & Variance Explained \\
\hline \multirow{5}{*}{ Work Overload } & WOM1 & .915 & \multirow{5}{*}{81.077} \\
\hline & WOM2 & .744 & \\
\hline & WOM3 & .947 & \\
\hline & WOM4 & .942 & \\
\hline & WOM5 & .938 & \\
\hline \multirow{6}{*}{ Job Insecurity } & JI1 & .923 & \multirow{6}{*}{78.013} \\
\hline & $\mathrm{JI} 2$ & .928 & \\
\hline & $\mathrm{JI} 3$ & .782 & \\
\hline & JI4 & .931 & \\
\hline & JI5 & .946 & \\
\hline & JI6 & .771 & \\
\hline & ES1 & .889 & \\
\hline & ES2 & .845 & \\
\hline & ES3 & .918 & \\
\hline
\end{tabular}




\begin{tabular}{|c|c|c|c|}
\hline Variables & Construct & Factor Loadings & Variance Explained \\
\hline \multirow[t]{4}{*}{ Employee Stress } & ES4 & .941 & \multirow[t]{4}{*}{74.619} \\
\hline & ES5 & .944 & \\
\hline & ES6 & .578 & \\
\hline & ES7 & .875 & \\
\hline \multirow{6}{*}{ Employee Performance } & EP1 & .937 & \multirow{6}{*}{78.845} \\
\hline & EP2 & .590 & \\
\hline & EP3 & .946 & \\
\hline & EP4 & .943 & \\
\hline & EP5 & .954 & \\
\hline & EP6 & .900 & \\
\hline
\end{tabular}

The above table shows two types of values for the constructs that were used to measure the independent, mediating and dependent variables of this study. These two values are factor loadings and the value of variance explained.

Factor loadings are used to examine the influence of each factor on its variable. Its value ranges from -1 to +1 . Value closer to 1 show that the influence is high and a value that is closer to zero shows that the influence is low. In the above table, the factor loadings for all the variables/ constructs are positive and near 1. The highest loading is 0.954 for the construct/factor EP5, whereas the lowest loading is 0.578 for the construct ES6.

The value of variance explained is used to examine the total variance explained by each construct. In simple words, it tells how much a variable is explained by each factor in the model. But for the purpose of understanding the cumulative value of variance explained is used for data analysis. The higher the value the more the variable is explained. In the above table, all the values are above 50 percent, which is the minimum acceptable level.

The total amount of variance in the original variables that was accounted for each component is known as total variance explained. Its variance explains by any construct should be greater than 0.50 . For that matter, it would be better to collect some more data for better cumulative variance. 


\subsection{Discriminant Validity}

Table 3. Validity Analysis

\begin{tabular}{|l|l|l|l|l|}
\hline & $\begin{array}{l}\text { Employee } \\
\text { Performance }\end{array}$ & $\begin{array}{l}\text { Employee } \\
\text { Stress }\end{array}$ & Job Insecurity & Work Overload \\
\hline $\begin{array}{l}\text { Employee } \\
\text { Emplormance }\end{array}$ & 1.000000 & 1.000000 & & \\
\hline Job Insecurity & -0.088943 & 0.369383 & 1.000000 & \\
\hline Work Overload & -0.139052 & 0.366183 & 0.457401 & 1.000000 \\
\hline
\end{tabular}

The above table shows the relationship between different variables. It can be seen from the table that the relationship between employee stress and employee performance is negative as its value is -0.39 , the relationship between job insecurity and employee performance $(-0.09)$ and work overload and employee performance $(-0.14)$ is also negative which means as any of these variables increases, employee performance decreases.

However; the relationship between job insecurity and employee stress (0.37) and work overload and employee stress (0.37) is positive which shows that when any of these variables increase, employee stress also increases.

\subsection{Composite Reliability}

Table 4. Composite Reliability

\begin{tabular}{|l|l|}
\hline & Composite Reliability \\
\hline Job Insecurity & 0.954557 \\
\hline Work Overload & 0.955080 \\
\hline Employee Stress & 0.952841 \\
\hline Employee Performance & 0.956247 \\
\hline
\end{tabular}

Composite Reliability indicates the overall reliability of the loaded items. The threshold for this is that it should be greater than 0.7 . So, in our case, the composite reliability of all the 


\section{Macrothink}

International Journal of Human Resource Studies

ISSN 2162-3058 2020, Vol. 10, No. 1

variables (Work Overload, Job Insecurity, Employee Stress, and Employee Performance) is greater than 0.7 .

\subsection{Average Variance Explained}

Table 5. Average Variance Explained

\begin{tabular}{|l|l|}
\hline & AVE \\
\hline Job Insecurity & 0.779449 \\
\hline Work Overload & 0.810742 \\
\hline Employee Stress & 0.746104 \\
\hline Employee Performance & 0.787656 \\
\hline
\end{tabular}

The threshold of AVE is that it should be greater than 0.5. So, in our case, the Average Variance Extracted of all the variables is above the threshold level and is suitable for analysis.

Table 6. Cronbach Alpha

\begin{tabular}{|l|l|}
\hline & Cronbachs Alpha \\
\hline Job Insecurity & 0.942163 \\
\hline Work Overload & 0.939631 \\
\hline Employee Stress & 0.939563 \\
\hline Employee Performance & 0.941597 \\
\hline
\end{tabular}

In order to check the reliability of data, Cronbach Alpha Test was conducted. Data is considered reliable if its value is greater than 0.70 (i.e. 70 percent). In this case, e, the values for all variables are greater than 90 percent, which indicates that data is highly reliable. 


\subsection{Beta Values and Item Loadings}

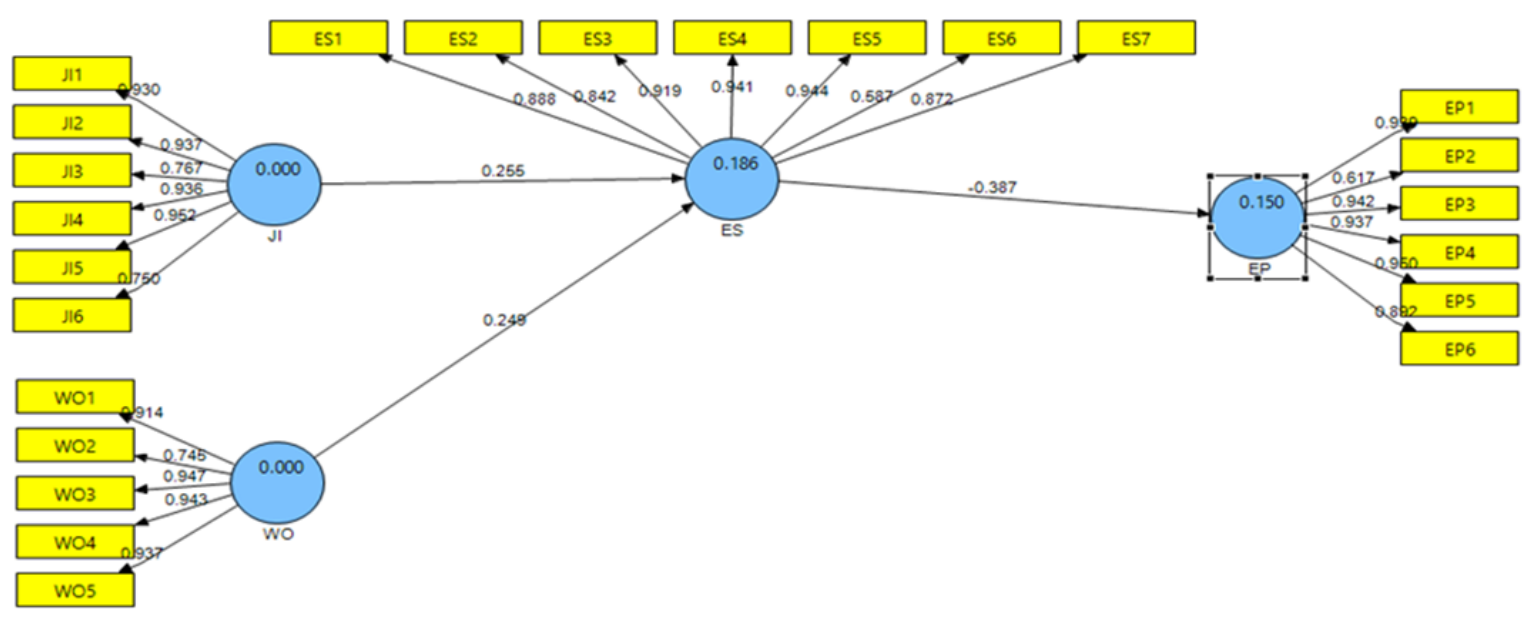

Figure 2. Beta Values

This is the theoretical model drawn in Smart PLS and tested accordingly to check the reliability, validity, correlation and significance of the hypotheses. The values on the arrow heads in between blue circles show the beta-values and the values in the circles show the $\mathrm{R}$-square values, meaning how much the variation in independent variable is being explained by independent variable. The beta value for Work Overload and Employee Stress is positive showing positive relationship with Employee Stress, Whereas, Job Insecurity is showing positive correlation value with Employee Stress means that Employees having job insecurity have more stress on them and the negative beta value between Employee Stress and Employee Performance depicts that if the employee stress increases their performance decreases and vice versa. These beta values only show relationships but do not indicate whether the relationship is significant or not. Hypothesis should be accepted or rejected on the basis of T-values, which are found by running the Bootstrapping test in Smart PLS.

\subsection{T-Values}

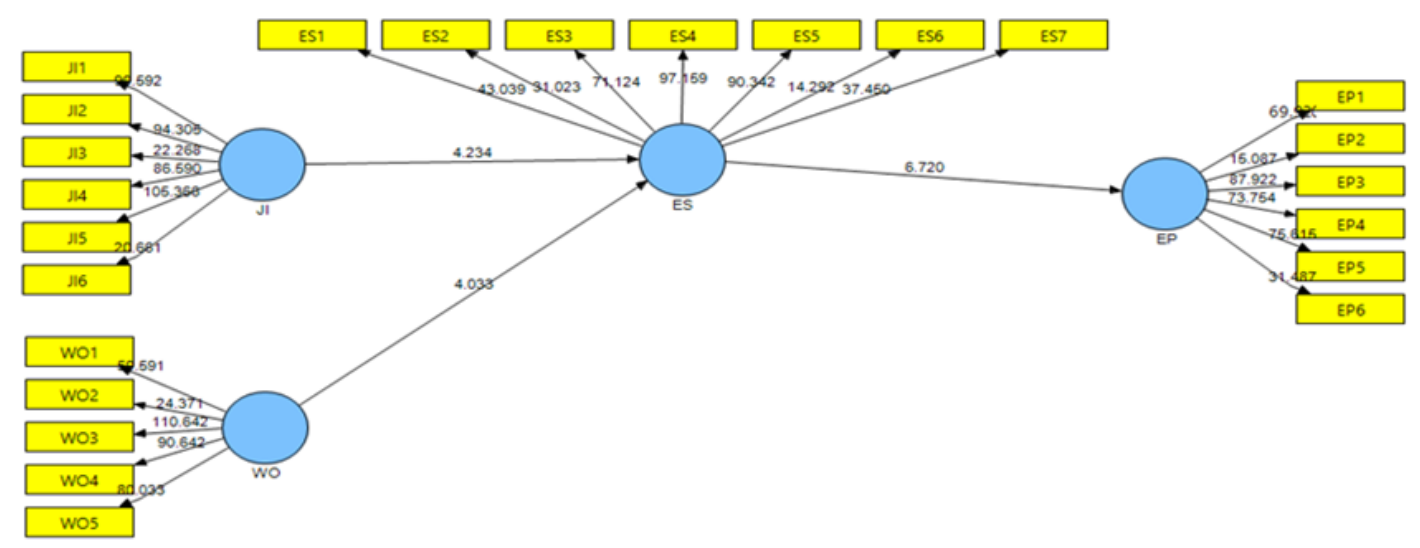

Figure 3. T- Values 


\section{Ml Macrothink}

International Journal of Human Resource Studies

ISSN 2162-3058 2020, Vol. 10, No. 1

After conducting PLS-Algorithm test on Smart PLS. Bootstrapping test was undertaken in order to check the significance of the hypotheses. For an accurate average, 350 respondents' data was bootstrapped to 5000 to check the impact of independent variables on the Dependent variable. Figure 3 shows T-values mentioned above connecting lines between blue circles. The t-value of or greater than 1.96 at a $5 \%$ confidence interval is said to be acceptable. It states that those greater than 1.96 have an impact on the dependent variable. The above figure clearly shows that t-values for almost all the relations between variables are greater than 1.96, just like for Hypothesis 1, Work overload has an impact on Employee Stress as it has at value of 4.033, which is greater than 1.96. The same is for Hypothesis 2 whose t-value which is also greater. Furthermore, the last hypothesis is also accepted as its t-value is greater than 1.96.

\subsection{Hypotheses Rejection/Acceptance}

Table 7. Summary of Hypotheses Testing

\begin{tabular}{|c|c|c|c|c|}
\hline HYPOTHESES & BETA & $R^{2}$ & T-VALUE & RESULTS \\
\hline$H 1: \| \rightarrow E S$ & 0.255 & 0.186 & 4.234 & ACCEPTED \\
\hline$H 2:$ WO $\rightarrow$ ES & 0.249 & 0.186 & 4.033 & ACCEPTED \\
\hline H3: ES $\rightarrow$ EP & -0.387 & 0.150 & 6.720 & ACCEPTED \\
\hline
\end{tabular}

Hypotheses were tested on Smart PLS using a bootstrapping approach with 5000 samples and 350 cases. The t-values were generated by bootstrapping that helped us in testing our hypothesis. The criteria used for accepting the hypothesis were that $\mathrm{t}$-values must be greater than 1.96 at 5 percent level of significance and R-square values should be greater than 0.10 and values around 0.35 are desirable. The results of the hypotheses are shown above along with beta and t-values.

\section{Conclusion}

\subsection{Crux of Model}

Model explains that the relationship between work overload and employee stress is positive and significant. As work overload increases, employee stress also increases. Consequently, the performance of the employees is declines.

Moreover, job insecurity and employee stress also has positive relationship that is significant. If job insecurity among employees increases, they experience stress and that in turn impedes their performance. Similarly, Employee Performance and Employee Stress have a negative and significant relationship. If employees experience high stress, they deliver low 
performance and vice versa.

So, in order to improve the performance of employees and the performance of the overall organization, managers should take measures to decrease work overload and job insecurity among employees and hence decrease employee stress.

\subsection{Managerial Implications}

Based on the results of this study, the two independent variables, Work overload, and Job Insecurity are important while considering employee stress at the workplace and ultimately the effect on employee performance. This analysis is also helpful for various organizations, public and private sector departments to visualize the stress level among the workforce and that how it affects a person and his job. Here, according to the results, job insecurity has more impact on stress rather than work overload which means that Job Insecurity has more adverse effects and management should put more emphasis on it in order to reduce stress and improve performance of their employees. Implications relevant for a broad style of workplaces can be drawn from this analysis and specifically for fast-food chains.

This study can be quite helpful for burgeoning fast-food industry in Pakistan. Firstly, the managers and employees would benefit from this research by becoming conscious of variables that influence the employee stress. Secondly, organizations can take steps to reduce the stress level among employees and find ways to decrease the work overload and level of job Insecurity. Consequently, organizations would be able eliminate obscure factors that impede employee performance.

To reduce Work Overload:

- In order to reduce Work overload, employees should not be held responsible for too many duties.

- Similarly, standards of performance should not be too high. These standards should be rationally attainable.

- Work responsibility should be adequate and according to the employee's capacity so that employees do not suffer from stress on the job that may hinder with their performance.

To reduce Job Insecurity:

- Employers should eliminate any perceived threat about loss of employment so employees can concentrate on their roles and do not get stressed about their jobs.

- Employers should foster a family-like culture for their employees and provide long term employment tracks.

To reduce Employee Stress:

Managers should make all possible work arrangements to hold training sessions or workshops for employees so that:

1. Employees are able to make decisions and take part actively in the decision-making 
process.

2. They are motivated and able to wear off feelings of depression.

3. They do not lack self-confidence and perform their duties to the fullest.

\subsection{Theoretical Implications}

It is established that given both factors i.e. job insecurity and work overload have a significant impact on employees' stress. However, Job Insecurity was comparatively found to have more impact on employees' stress as compared to work overload. Moreover, employee stress had an impact on employee performance and this result was significant.

The careful implications of this research can help the Fast-food industry of Pakistan, to curb these harmful factors as industry flourishes so employers can decrease employee stress and increase their performance.

\subsection{Limitations \& Recommendations}

Organizations should consider their employees as valuable assets in order to become a successful business.

Organizations should also conduct effective training programs in order to help the employee understand their role and importance in the organization so that their insecurity can be minimized.

Moreover, the workload should be according to the capacity of each employee, irrespective of their ranks. Human resource is the essence of every organization so they should not be exploited.

Limitations of this study include:

- The population of our study was large and diverse so it was impossible to cover every element of the population. Our sample size was limited to 350 respondents.

- Furthermore; data was collected from the urban cities of Pakistan and thus the results of this study would be applicable to Lahore, Karachi, and Islamabad and cannot be generalized for other cities of Pakistan. Future researchers may consider other cities as well.

- Some respondents may have given untrue information, filled out survey in a hurry or with lack of interest, so there is a possibility of biased responses.

- The research took Work Overload and Job Insecurity into consideration while evaluating Employee performance. Other variables like "Work-Life Balance", "Role Ambiguity" and "Relationship with Subordinates" can also be taken into consideration while conducting future research.

- The research took Employee stress as mediating variable and Employee Performance as a dependent variable, however; other variables like "Job Satisfaction", "Commitment to the Organization", "Employee Involvement" and "Employee Turnover" can also be used by future researchers. 


\section{References}

Aczel, A. D., \& Sounderpandian, J. (1999). Complete business statistics. Boston, MA: Irwin/McGraw Hill.

Ashford, S. J. (1989). Content, causes, and consequences of job insecurity: A theory-based measure and substantive test. Academy of Management, 803-829. https://doi.org/10.2307/256569

Azam, M. (2017, October 11). Pakistan's food sector thriving as foreign franchises increase their food-print. Retrieved from https://www.monthlybrands.com.pk/: https://www.monthlybrands.com.pk/whats-hot-articles-blogs/news-around/pakistans-food-sec tor-thriving-foreign-franchises-increase-food-print/

Blaug, R., Kenyon, A., \& Lekhi, R. (2007). Stress at work. The work foundation.

Brown, M., \& Benson, J. (2005). Managing to Overload? Work Overload and Performance Appraisal Processes. Sage Publications. https://doi.org/10.1177/1059601104269117

Colligan, T. W., \& Higgins, E. M. (2005). Workplace Stress: Etiology and Consequences. Journal of Workplace Behavioral Health. https://doi.org/10.1300/J490v21n02_07

Collis, J., \& Hussey, R. (2003). Business Research. Basingstoke: Palgrave Macmillan.

Cousins, R. (2004). Management Standards' and work-related stress in the UK: Practical development. Work Stress. An International Journal of Work, Health \& Organisations. https://doi.org/10.1080/02678370410001734322

CUPE, C. U. (2003). Enough workplace stress: organizing for change. Ottawa: CUPE.

Darden, W. R., \& Babin, B. J. (1994). Exploring the Concept of Affective Quality: Expanding the Concept of Retail Personality. Journal of Business Research, 101-109. https://doi.org/10.1016/0148-2963(94)90014-0

Davy, J., Kinicki, A., \& Scheck, C. (1997). A test of job security's direct and mediated effects on withdrawal cognitions. Journal of Organizational Behavior, 323-349. https://doi.org/10.1002/(SICI)1099-1379(199707)18:4<323::AID-JOB801>3.0.CO;2-\#

Deadrick, D. L., \& Gardner, D. G. (1997). Distributional ratings of performance levels and variability: An examination of rating validity in a field setting. Group \& Organization Management, 317-342. https://doi.org/10.1177/1059601197223002

DeFrank, R., \& Ivancevich, J. (1998). Stress on the Job: An Executive Update. The Academy of Management Executive, 55-66. https://doi.org/10.5465/ame.1998.1109050

Duxbury, L., \& Higgins, C. (2001). Duxbury, Linda \& Higgins, Chris. (2001). Work-life Balance in the New Millennium: Where Are We? Where Do We Need to Go? Ottawa: Canadian Policy Research Networks Inc.

Edwards, J. R., Caplan, R. D., \& Van Harrison, R. (1998). Person-environment fit theory. Theories of organizational stress. 


\section{Macrothink}

International Journal of Human Resource Studies

ISSN 2162-3058

2020, Vol. 10, No. 1

Greenhalgh, L. (1984). Job insecurity: Toward conceptual clarity. Academy of management review, 438-448. https://doi.org/10.5465/amr.1984.4279673

Güngör, P. (2011). The relationship between reward management system and employee performance with the mediating role of motivation: A quantitative study on global banks. Procedia-Social and Behavioral 1510-1520. https://doi.org/10.1016/j.sbspro.2011.09.029

Hartley, D. J. (1991). Job Insecurity. In D. J. J. Hartley. The SAGE Handbook of Organizational Behavior, 1, 1216. SAGE Publications.

Heaney, C., Israel, B., \& House, J. (1994). Chronic job insecurity among automobile workers: Effects on job satisfaction and health. Social Science \& Medicine, 1431-1437. https://doi.org/10.1016/0277-9536(94)90281-X

Ivancevich, J. (1985). Predicting Absenteeism from Prior Absence and Work Attitudes. Academy of Management, 219-228. https://doi.org/10.5465/256070

Iverson, R., \& Maguire, C. (2000). The Relationship Between Job and Life Satisfaction: Evidence from a Remote Mining Community. Human Relations, Sage Publications, 184. https://doi.org/10.1177/0018726700536003

Kahn, R. L., \& Byosiere, P. (1992). Stress in organizations. In Handbook of industrial and organizational psychology, 571-650. Consulting Psychologists Press.

Karasek Jr, R. A. (1979). Job demands, job decision latitude, and mental strain: Implications for job redesign. Administrative science quarterly, 285-308. https://doi.org/10.2307/2392498

Lazarus, R. (1966). Psychological stress and the coping process. McGraw-Hill.

Lee, Y. R. (2011). The effects of internal marketing, job satisfaction and service attitude on job performance among high-tech firm. African Journal of Business Management, 2-12.

Luthans, F. (1999). Reinforce for performance: The need to go beyond pay and even rewards. Academy of Management Perspectives, 49-57. https://doi.org/10.5465/ame.1999.1899548

Macky, K., \& Boxall, P. (2007). The relationship between 'high-performance work practices' and employee attitudes: an investigation of additive and interaction effects. The International Journal of Human Resource Management, 537-567. https://doi.org/10.1080/09585190601178745

Marcatto, F., Colautti, L., Larese, F., Luis, O., \& Ferrante, D. (2014). The HSE Management Standards Indicator Tool: Concurrent and construct validity. Occupational medicine(Oxford, England). https://doi.org/10.1093/occmed/kqu038

Michie, S., \& Williams, S. (2003). Reducing work related psychological ill health and sickness absence: a systematic literature review. Occupational and environmental medicine. https://doi.org/10.1136/oem.60.1.3 


\section{Ml Macrothink}

International Journal of Human Resource Studies

ISSN 2162-3058

2020, Vol. 10, No. 1

Newton, T. J., \& Keenan, A. (1987). Role stress reexamined: An investigation of role stress predictors. Organizational behavior and human decision processes, 346-368. https://doi.org/10.1016/0749-5978(87)90021-5

Pelletier, K. (1992). "Mind-body health: research, clinical and applications. American Journal of Health Promotion, 345-358. https://doi.org/10.4278/0890-1171-6.5.345

Pfeffer, J. (1994). Competitive advantage through people. California management review. https://doi.org/10.2307/41165742

Rees, C. J., \& Redfern, D. (2000). Recognising the perceived causes of stress-a training and development perspective. Industrial and commercial Training. https://doi.org/10.1108/00197850010372197

Riga, A. (2006). Business awakes to cost of stress: $20 \%$ of payroll. Montreal: The Gazette.

Rizzo, J., House, R., \& Lirtzman, S. (1970). Role Conflict and Ambiguity in Complex Organizations. Administrative Science Quarterly, 150-163. https://doi.org/10.2307/2391486

Selye, H. (1956). The stress of life. New York: McGraw-Hill.

Spector, P. E., \& Jex, S. M. (1998). Development of four self-report measures of job stressors and strain: Interpersonal Conflict at Work Scale, Organizational Constraints Scale, Quantitative Workload Inventory, and Physical Symptoms Inventory. Journal of occupational health psychology. https://doi.org/10.1037/1076-8998.3.4.356

Stevens, J. M., Beyer, J. M., \& Trice, H. M. (1978). Assessing personal, role, and organizational predictors of managerial commitment. Academy of management journal, 380-396. https://doi.org/10.2307/255721

Sverke, M. H. (2002). No security: A meta-analysis and review of job insecurity and its consequences, 7(3) . Journal of Occupational Health Psychology, 242-264. https://doi.org/10.1037/1076-8998.7.3.242

Taylor, S. E., Repetti, R. L., \& Seeman, T. (1997). Health psychology: what is an unhealthy environment and how does it get under the skin? Annual review of psychology, 411-447. https://doi.org/10.1146/annurev.psych.48.1.411

Vagg, P. R., \& Spielberger, C. D. (1998). Occupational stress: measuring job pressure and organizational support in the workplace. Journal of occupational health psychology. https://doi.org/10.1037/1076-8998.3.4.294

Vermunt, R., \& Steensma, H. (2005). How can justice be used to manage stress in organizations. In J. Greenberg, \& J. A. Colquitt, Handbook of organizational justice, (pp. 383-410).

Williams, C. (2007). Research Methods. Journal of Business \& Economics Research.

Witte, H. D. (1999). Job Insecurity and Psychological Well-being: Review of the Literature and Exploration of Some Unresolved Issues. European Journal of Work and Organizational 
Psychology, 155-177. https://doi.org/10.1080/135943299398302

\section{Appendix}

\section{APPENDIX-A}

Questionnaire

Impact of Job Insecurity \& Work overload on Employee Performance with mediating role of Employee Stress in Fast-food industry of Pakistan

Respected Respondent:

This survey is conducted to know some of the factors that affect the performance of workers in the fast-food industry of Pakistan. Your response will only be used for academic purpose and all information provided will remain confidential. Thank you for your cooperation!

Gender:

Age:

Working Area:

Income:

\begin{tabular}{|c|c|c|c|c|c|}
\hline Work Overload & $\begin{array}{l}\text { Strongly } \\
\text { disagree }\end{array}$ & Disagree & Neutral & Agree & $\begin{array}{l}\text { Strongly } \\
\text { Agree }\end{array}$ \\
\hline $\begin{array}{l}\text { My job requires me to work too } \\
\text { fast. }\end{array}$ & 1 & 2 & 3 & 4 & 5 \\
\hline I often have to work overtime. & 1 & 2 & 3 & 4 & 5 \\
\hline I feel pressured. & 1 & 2 & 3 & 4 & 5 \\
\hline I often feel rushed. & 1 & 2 & 3 & 4 & 5 \\
\hline $\begin{array}{l}\text { My job gives me very little time } \\
\text { to get everything done. }\end{array}$ & 1 & 2 & 3 & 4 & 5 \\
\hline Job Insecurity & $\begin{array}{l}\text { Strongly } \\
\text { disagree }\end{array}$ & Disagree & Neutral & Agree & $\begin{array}{l}\text { Strongly } \\
\text { Agree }\end{array}$ \\
\hline $\begin{array}{l}\text { I feel insecure about the future of } \\
\text { my job. }\end{array}$ & 1 & 2 & 3 & 4 & 5 \\
\hline $\begin{array}{l}\text { I think I might lose my job in the } \\
\text { near future. }\end{array}$ & 1 & 2 & 3 & 4 & 5 \\
\hline Chances are, I will soon lose my & 1 & 2 & 3 & 4 & 5 \\
\hline
\end{tabular}




\begin{tabular}{|c|c|c|c|c|c|}
\hline job. & & & & & \\
\hline I am sure, I can keep my job. & 1 & 2 & 3 & 4 & 5 \\
\hline $\begin{array}{l}\text { I am worried about having to } \\
\text { leave my job before I would like } \\
\text { too. }\end{array}$ & 1 & 2 & 3 & 4 & 5 \\
\hline $\begin{array}{l}\text { I feel uneasy about losing my job } \\
\text { in the near future. }\end{array}$ & 1 & 2 & 3 & 4 & 5 \\
\hline Employee Stress & $\begin{array}{l}\text { Strongly } \\
\text { disagree }\end{array}$ & Disagree & Neutral & Agree & $\begin{array}{l}\text { Strongly } \\
\text { Agree }\end{array}$ \\
\hline $\begin{array}{l}\text { I am capable of making } \\
\text { decisions. }\end{array}$ & 1 & 2 & 3 & 4 & 5 \\
\hline I could not overcome difficulties. & 1 & 2 & 3 & 4 & 5 \\
\hline $\begin{array}{l}\text { I am feeling unhappy and } \\
\text { depressed. }\end{array}$ & 1 & 2 & 3 & 4 & 5 \\
\hline I am losing confidence. & 1 & 2 & 3 & 4 & 5 \\
\hline I am able to concentrate. & 1 & 2 & 3 & 4 & 5 \\
\hline I am under stress. & 1 & 2 & 3 & 4 & 5 \\
\hline $\begin{array}{l}\text { I am thinking of self as } \\
\text { worthless. }\end{array}$ & 1 & 2 & 3 & 4 & 5 \\
\hline Employee Performance & $\begin{array}{l}\text { Strongly } \\
\text { disagree }\end{array}$ & Disagree & Neutral & Agree & $\begin{array}{l}\text { Strongly } \\
\text { Agree }\end{array}$ \\
\hline $\begin{array}{l}\text { I was able to fulfill my } \\
\text { Responsibilities. }\end{array}$ & 1 & 2 & 3 & 4 & 5 \\
\hline $\begin{array}{l}\text { I think customers/clients were } \\
\text { satisfied with my work. }\end{array}$ & 1 & 2 & 3 & 4 & 5 \\
\hline
\end{tabular}




\begin{tabular}{|l|l|l|l|l|l|}
\hline $\begin{array}{l}\text { I came up with creative ideas at } \\
\text { work. }\end{array}$ & 1 & 2 & 3 & 4 & 5 \\
\hline $\begin{array}{l}\text { I was able to meet my } \\
\text { appointments. }\end{array}$ & 1 & 2 & 3 & 4 & 5 \\
\hline $\begin{array}{l}\text { I was able to perform my work } \\
\text { well with minimal time and } \\
\text { effort. }\end{array}$ & 1 & 2 & 3 & 4 & 5 \\
\hline $\begin{array}{l}\text { I worked at keeping my job skills } \\
\text { up-to-date. }\end{array}$ & 1 & 2 & 3 & 4 & 5 \\
\hline
\end{tabular}

\section{APPENDIX-B}

The tables below show the results of KMO and Bartlett tests for each variable, separately.

Table 8. KMO and Bartlett's Test (Work Overload)

\section{KMO and Bartlett's Test}

Kaiser-Meyer-Olkin Measure of Sampling Adequacy. .808

Bartlett's Test of Sphericity

\begin{tabular}{l|l} 
Approx. Chi-Square & 2106 \\
\hline Df & 10 \\
\hline Sig. & .000
\end{tabular}

Table 9. KMO and Bartlett's Test (Job Insecurity)

\section{KMO and Bartlett's Test}

Kaiser-Meyer-Olkin Measure of Sampling Adequacy. .672

Bartlett's Test of Sphericity

\begin{tabular}{l|l} 
Approx. Chi-Square & 3084. \\
\hline Df & 15 \\
\hline Sig. & .000
\end{tabular}

Table 10. KMO and Bartlett's Test (Employee Stress) 


\section{KMO and Bartlett's Test}

\begin{tabular}{|l|l|l|}
\hline \multicolumn{2}{|l|}{ Kaiser-Meyer-Olkin Measure of Sampling Adequacy. } & .876 \\
\hline Bartlett's Test of Sphericity & Approx. Chi-Square & 2873.442 \\
\cline { 2 - 3 } & Df & 21 \\
\cline { 2 - 3 } & Sig. & .000 \\
\hline
\end{tabular}

Table 11. KMO and Bartlett's Test (Employee Performance)

\section{KMO and Bartlett's Test}

Kaiser-Meyer-Olkin Measure of Sampling Adequacy. 882

Bartlett's Test of Sphericity

\begin{tabular}{|l|l|}
\hline Approx. Chi-Square & 2508.747 \\
\hline Df & 15 \\
\hline Sig. & .000 \\
\hline
\end{tabular}

The tables below show the values of total variance explained for each variable used in this study, separately.

Table 12. Total Variance Explained (Work Overload)

\section{Total Variance Explained}

\begin{tabular}{|l|l|l|l|l|l|l|}
\hline \multirow{2}{*}{ Component } & \multicolumn{3}{|l|}{ Initial Eigenvalues } & \multicolumn{3}{l|}{ Extraction Sums of Squared Loadings } \\
\cline { 2 - 7 } & Total & $\begin{array}{l}\% \quad \text { of } \\
\text { Variance }\end{array}$ & Cumulative \% & Total & $\begin{array}{l}\% \quad \text { of } \\
\text { Variance }\end{array}$ & Cumulative \% \\
\hline 1 & 4.054 & 81.077 & 81.077 & 4.054 & 81.077 & 81.077 \\
\hline 2 & .530 & 10.603 & 91.680 & & & \\
\hline 3 & .291 & 5.819 & 97.499 & & & \\
\hline 4 & .078 & 1.564 & 99.063 & & & \\
\hline
\end{tabular}




\begin{tabular}{|l|l|l|l|l|l|l|}
\hline 5 & .047 & .937 & 100.000 & & & \\
\hline
\end{tabular}

Extraction Method: Principal Component Analysis.

Table 13. Total Variance Explained (Job Insecurity)

\begin{tabular}{|c|c|c|c|c|c|c|}
\hline \multicolumn{7}{|c|}{ Total Variance Explained } \\
\hline \multirow[t]{2}{*}{ Component } & \multicolumn{3}{|c|}{ Initial Eigenvalues } & \multicolumn{3}{|c|}{ Extraction Sums of Squared Loadings } \\
\hline & Total & $\begin{array}{l}\% \text { of } \\
\text { Variance }\end{array}$ & Cumulative $\%$ & Total & $\begin{array}{l}\% \text { of } \\
\text { Variance }\end{array}$ & Cumulative $\%$ \\
\hline 1 & 4.681 & 78.013 & 78.013 & 4.681 & 78.013 & 78.013 \\
\hline 2 & .868 & 14.469 & 92.482 & & & \\
\hline 3 & .230 & 3.833 & 96.315 & & & \\
\hline 4 & .159 & 2.648 & 98.963 & & & \\
\hline 5 & .039 & .645 & 99.608 & & & \\
\hline 6 & .024 & .392 & 100.000 & & & \\
\hline \multicolumn{7}{|c|}{ Extraction Method: Principal Component Analysis. } \\
\hline \multicolumn{7}{|c|}{ Table 14. Total Variance Explained (Employee Stress) } \\
\hline \multicolumn{7}{|c|}{ Total Variance Explained } \\
\hline \multirow[t]{2}{*}{ Component } & \multicolumn{3}{|c|}{ Initial Eigenvalues } & \multicolumn{3}{|c|}{ Extraction Sums of Squared Loadings } \\
\hline & Total & $\begin{array}{l}\% \text { of } \\
\text { Variance }\end{array}$ & Cumulative \% & Total & $\begin{array}{l}\% \text { of } \\
\text { Variance }\end{array}$ & Cumulative $\%$ \\
\hline 1 & 5.223 & 74.619 & 74.619 & 5.223 & 74.619 & 74.619 \\
\hline 2 & .853 & 12.183 & 86.802 & & & \\
\hline 3 & .393 & 5.610 & 92.412 & & & \\
\hline
\end{tabular}




\begin{tabular}{|l|l|l|l|l|l|l|}
\hline 4 & .235 & 3.352 & 95.764 & & & \\
\hline 5 & .166 & 2.367 & 98.131 & & & \\
\hline 6 & .091 & 1.301 & 99.432 & & & \\
\hline 7 & .040 & .568 & 100.000 & & & \\
\hline
\end{tabular}

Extraction Method: Principal Component Analysis.

Table 15. Total Variance Explained (Employee Performance)

\begin{tabular}{|c|c|c|c|c|c|c|}
\hline \multicolumn{7}{|c|}{ Total Variance Explained } \\
\hline \multirow[t]{2}{*}{ Component } & \multicolumn{3}{|c|}{ Initial Eigenvalues } & \multicolumn{3}{|c|}{ Extraction Sums of Squared Loadings } \\
\hline & Total & $\begin{array}{l}\% \text { of } \\
\text { Variance }\end{array}$ & Cumulative \% & Total & $\begin{array}{l}\% \text { of } \\
\text { Variance }\end{array}$ & Cumulative \% \\
\hline 1 & 4.731 & 78.845 & 78.845 & 4.731 & 78.845 & 78.845 \\
\hline 2 & .734 & 12.235 & 91.080 & & & \\
\hline 3 & .216 & 3.606 & 94.686 & & & \\
\hline 4 & .152 & 2.530 & 97.217 & & & \\
\hline 5 & .111 & 1.842 & 99.059 & & & \\
\hline 6 & .056 & .941 & 100.000 & & & \\
\hline
\end{tabular}

\section{Copyright Disclaimer}

Copyright for this article is retained by the author(s), with first publication rights granted to the journal.

This is an open-access article distributed under the terms and conditions of the Creative Commons Attribution license (http://creativecommons.org/licenses/by/4.0/). 